\title{
TOWARDS DEVELOPING A CLOUD-BASED EDUCATION AS A SERVICE (CEAAS) MODEL FOR CLOUD COMPUTING ADOPTION IN HIGHER EDUCATION INSTITUTIONS
}

\author{
Yousef A. M. Qasem, Rusli Abdullah, Rodziah Atan, Yusmadi Yah Jusoh
}

Faculty of Computer Science and Information Technology, University Putra Malaysia *Corresponding Author Email: y.alsharaei@gmail.com,rusli@upm.edu.my,rodziah@upm.edu.my,yusmadi@upm.edu.my

This is an open access article distributed under the Creative Commons Attribution License, which permits unrestricted use, distribution, and reproduction in any medium, provided the original work is properly cited

\section{ARTICLE DETAILS \\ ABSTRACT \\ Article History: \\ Received 12 November 2017 Accepted 12 December 2017 Available online 1 January 2018 \\ This paper attempts to provides a distinctive contribution for the body of knowledge in study-ing the theoriticalmodels and factors affecting cloud computing (CC) adoption in higher educa-tion institutions (HEIs) at organizational level incorporating four dominant models; Technology-organization-environment (TOE) theory, The Fit-Viability Model (FVM), Diffusion of Innova-tion (DOI) Theory, and Institutional (INT) theo-ry; to deliver cloud- based education as a service (CEaaS) in HEIs. \\ KEYWORDS

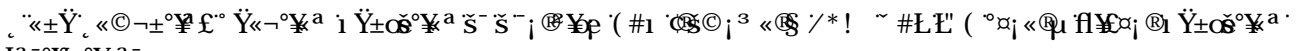

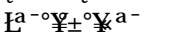

\section{INTRODUCTION}

Cloud computing (CC) can be considered as a 'model for enabling ubiquitous, convenient, on-demand network access', which can be accessed almost immediately with little effort or 'service provider interaction' [1].

The basis of the XaaS, 'deliver everything as a service' with relation to information technology is itself a technological revolution. The idea of this service is that it can be accessed from anywhere relatively easily and cheaply and can be implemented on a 'pay per use' basis [2].

Within the wider context of education, Higher Education Institutions (HEI's) ; Tertiary Education at a University or recognised institution leading to a formally recognised degree qualification ; are faced with a dilemma, on the one hand they are required to keep up with the speed of technological change, whilst at the same time they are having to 'provide a quality and an affordable education service to the education community'. This constant challenge means that HEI's continue to improve their services to make them ever more efficient whilst at the same time are seeking, 'opportunities to rationalise the way they manage their resources' [3]. CC arises as a promising alternative for HEI's to reduce costs and increase efficiency whilst at the same time contributing to the longer term sustainability of Higher Education.

On a more general note, the adoption of any new technology refers to the decision of any individual or organization to make use of an innovation which goes through a set different stages, these being the; '[i.e. intention (persuasion stage), adoption (decision stage), and routinization (implementation stage)]' [4].

If CC technology is adopted by all involved in the university, the students, the lecturers, the faculty administrators and so on, there is no doubt that this will improve the educational processes within Universities on the whole. Existing research theories and models have sought to highlight these facts and can be found in tables 1 .

\section{METHODOLOGY}

To be able to include the various and wide list of theories and factors from past search and filter them, we undertook a systematic approach of collaborating, matching, filtering, and consolidating all of the information and ideas from the various research that was studied in the literature review [5]. Eventually, the most related theories and the most frequently factors were selected.

\section{RESULTS}

Based on a systematic approach, we derived the following organisationalbased factors from the empirical studies (table 2) [5].

Table 1: Theoretical models for examining factors affecting the adoption of cloud computing in HEIs

\begin{tabular}{|c|l|c|}
\hline Code & \multicolumn{1}{|c|}{ Theory/model } & Source \\
\hline 1 & (DOI and TAM) & {$[6]$} \\
\hline 2 & TOE Framework & {$[7]$} \\
\hline 3 & $\begin{array}{l}\text { (Institutional Theory and Capabil- } \\
\text { ity Approach) }\end{array}$ & {$[8]$} \\
\hline 4 & COBIT 5 Framework & {$[9]$} \\
\hline 5 & Fit Viability (FVM) model & {$[10]$} \\
\hline
\end{tabular}

Table 2: Organizational-based factors influencing CC adoption in HEIs

\begin{tabular}{|r|l|l|}
\hline \multicolumn{2}{|l|}{$\begin{array}{l}\text { Code } \\
\text { Innovation Factors }\end{array}$} & Source \\
\hline 1. & Relative Advantage & \\
\hline 2. & Complexity & {$[6],[7]$} \\
\hline 3. & Compatibility & {$[6],[7]$} \\
\hline Technological Factors & {$[6],[7]$} \\
\hline 4. & Risk & \\
\hline 5. & Security & {$[6],[11]$} \\
\hline & & {$[6],[11],[7]$} \\
\hline Contextual Factors & \\
\hline 6. & Infrastructure & \\
\hline Usability Factors & {$[6],[9]$} \\
\hline 7. & Usefulness & \\
\hline 8. & Ease of Use & {$[6],[11]$} \\
\hline
\end{tabular}


There are a great number of scientific contributions that address the topic from different perspectives trying to harness CC services for Education. Despite the existence of research, there is sadly a lack of empirical evidence surrounding the adoption of CC technology in HEI's and gaps do still exist in the research at organizational-level [12]. In an attempt to plug these gaps, this paper tries to develope a cloud-based EaaS model for CC adoption in HEIs at organizational-level.

This research attempts to provides a distinctive contribution for the body of knowledge in studying the theoriticalmodels and factors affecting CC adoption at organizational level incorporating four dominant models; Technology-organization-environment (TOE) theory, The Fit-Viability Model (FVM), Diffusion of Innovation (DOI) Theory, and Institutional (INT) theory; to provide CEaaS initiatives in HEIs (Figure 1). To make a precise decision before engaging in educational cloud-based initiatives, the study provides a foundation for the decision makers in HEIs whether or not to approve CC services in their institutions.

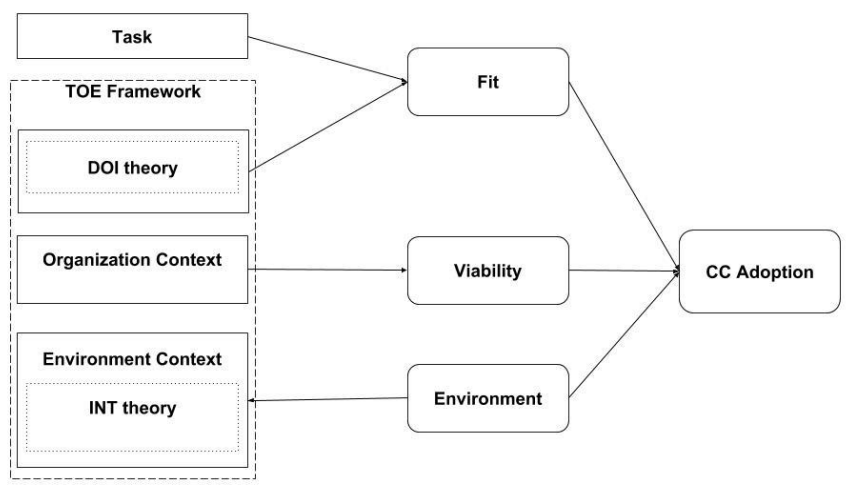

Figure 1: Cloud Computing Adoption Theoritical Model

\section{DISCUSION}

The intention of this study was to provide significant important implications for research on CC and its outcome on HEIs by providing a distinctive contribution for the body of knowledge in studying the dominant theoretical models and most frequentlyfactors affecting CC adoption at organizational level. The full empirical study may help the decision makers in HEIs to have a clear understanding before engaging in educational cloud-based initiatives.

As a conclusion, the paper has proposed a CEaaS model and its architecture to facilitate the needs of the main stakeholders in cloud education community the aim of increasing efficiency and effectiveness of education and learning process in HLIs.

As a future work, the outcome of this study is in its fundamental theoretical concept; therefore; validation and adaptation of the model to a set of HEIs is recommended. To examine the propositions recommended here, measure items should be obtained, and a survey instrument that is dependent on the measured items proposed should be developed.

\section{REFERENCES}

[1] Mell, P., Grance, T. 2011. The NIST definition of cloud computing. National Institute of Standards and Technology U.S. Department of Commerce, 800-145.

[2] Armbrust, M., Fox, A., Griffith, R., Joseph, A.D., Katz, R., Konwinski, A., Lee, G., Patterson, D., Rabkin, A., Stoica, I., Zaharia, M. 2010. A view of cloud computing. Communications of the ACM, 53(4), 50-58.

[3] Sultan, N. 2010. Cloud computing for education: A new dawn. International Journal of Information Management, 30(2), 109-116.
[4] Rogers, E.M. 2010. Diffusion of innovations. Simon and Schuster. Diffusion of Innovations, 4th Edition.

[5] Srinivasan, A., Quadir, M.A., Vijayakumar, V. 2015. Hybrid Cloud for Educational Sector. Procedia Computer Science, 50, 37-41.

[6] Sabi, H.M., Uzoka, F.M.E., Langmia, K., Njeh, F.N., Tsuma, C.K. 2017. A cross-country model of contextual factors impacting cloud computing adoption at universities in sub-Saharan Africa. Information Systems Frontiers, 1-24.

[7] Tashkandi, A.N., Al-Jabri, I.M. 2015. Cloud computing adoption by higher education institutions in Saudi Arabia: an exploratory study. Cluster Computing-the Journal of Networks Software Tools and Applications, 18(4), 1527-1537.

[8] Dahiru, A.A., Bass, J.M., Allison, I.K. 2015. Cloud computing adoption in sub-Saharan Africa: An analysis using institutions and capabilities. International Conference on Information Society, i-Society 2014.

[9] Surya, G.S.F., Surendro, K., Ieee. 2014. E-Readiness Framework For Cloud Computing Adoption In Higher Education. 2014 International Conference of Advanced Informatics: Concept, Theory and Application (ICAICTA), 278-282.

[10] Tjan, A.K. 2001. Finally, a way to put your Internet portfolio in order. Harvard business review, 79(2), 76-85, 156.

[11] Yuvaraj, M. 2015. Problems and prospects of implementing cloud computing in university libraries: A case study of Banaras Hindu University library system. Library Review, 64(8-9), 567-582.

[12] Sabi, H.M., Uzoka, F.M.E., Langmia, K., Njeh, F.N. 2016. Conceptualizing a model for adoption of cloud computing in education. International Journal of Information Management, 36(2), 183-191. 